\title{
Capital Structure, Profitability and Firm's Value: Evidence from Jordan
}

\author{
Dr. Osama J. Al-Nsour* \\ P.O. Box 19117 Al-Salt, Jordan \\ Department of Financial and Management Sciences - Al-Balqa' Applied University \\ Akram "Moh'd Irfan" Al-Muhtadi \\ Department of Financial and Management Sciences - Al-Balqa' Applied University
}

\begin{abstract}
The purpose of this study is to empirically examine the effect of capital structure and profitability on firm's value. The study sample included (41) manufacturing companies Out of a total of (63) companies listed on Amman Stock Exchange (ASE) over the five years period (2014-2018). To test the study hypotheses and to achieve its objectives, data was obtained from (ASE) database and annual reports issued by Jordanian manufacturing public shareholding companies. Thus, capital structure (which have been measured by leverage and debt to equity ratio) and profitability (which have been measured by ROA and ROE) are presented as independent variables, while the firm's value is articulated as the dependent variable using market value and Tobin's $Q$ as firm's value measure. Multiple regression analysis is undertaken to analyse the potential effect of capital structure and profitability on firm's value.The study reveals different results by using different firm's value measures. When using the first model (market value) the results found that DER has significant effect on market value and the direction of the relationship is positive, while ROA has significant effect on market value and the direction of the relationship is negative. However, when the second model (Tobin's $Q$ ) used the results found that there is no significant effect between all of the independent variables (capital structure and profitability variables) and Tobin's $Q$.
\end{abstract}

Keywords: capital structure, profitability, firm's value, manufacturing companies, Jordan

DOI: $10.7176 /$ RJFA/10-20-07

Publication date:October $31^{\text {st }} 2019$

\section{Introduction}

The interaction between capital structure, profitability and firm's value is an important issue that has received considerable attention in corporate finance literature. Modern capital structure theories begin in 1958 by Modigliani and Miller's classical paper which provided the motivation for the huge literature concerning capital structure (Al-Nsour and Jresat, 2018). Capital structure represents the proportions of the firm's financing from current and long-term debt and equity (Ross et.al. 2002). (Modigliani and Miller, 1958) argued that a firm choice of capital structure does not have any positive effect on firm's value. The main proposition of Modigliani and Miller's theory is that, under a number of restrictive assumptions, the value of the firm is independent from its financial structure. These assumptions include the absence of taxes, bankruptcy costs, equality of borrowing and lending rates, and the independence of the companies productive activates from its financing decisions. (Siam, et al., 2005). Then, Modigliani and Miller in 1963 argue that, when there are corporate taxes, and when interest payment are tax deductible, 100 per cent debt financing is optimal, which means that the firm's value increases as debt increases (Mouna, et al., 2017). Also they gave a cautionary warning that the firm will not necessary maximize their value by using 100 per cent debt due to bankruptcy costs (Al-Nsour and Jresat, 2018). Since then, three different theories on the subject have been developed: The Static Trade-Off Theory, Pecking-Order Theory, and the Agency Theory (Musah, 2017). According to the Static Trade-Off Theory an optimal capital structure is obtainable; where the tax benefit of debt is equal to the leverage associated costs which may include cost of financial distress and bankruptcy while investment decision and firm asset are held constant. Pecking-Order Theory posits that it is difficult to determine the optimal capital structure because firms make use of first equity capital, then debt and lastly equity in financing new investments. Equity capital appears both at the start and end of the pecking order. Agency Theory was proposed by (Jensen and Meckling, 1976). This theory states that an optimal capital structure is attainable by reducing the costs resulting from conflict between managers and the shareholders. Leverage can be used to monitor the managers to pursue the firm objectives and not to maximize their interest at the expense of the owners. Therefore cost is reduced leading to efficiency which will enhance firm's performance (Musah, 2017). Moreover, poor capital structure can result in high cost of capital, decreasing the NPVs of projects and making them unacceptable. Effective capital structure can lower the cost of capital, increasing the NPVs of projects, thereby increasing the firm's value (Gitman, 2003).

On the other hand, another factor may affect the firm's value is profitability. Profitability is an extremely important creator of value within the firm; a firm can attain profitability by taking advantages of economics of scale, exploring avenues of cost reduction, exterminating all overheads that fail to add value to the product and 
rendering costs that do not enhance the consumer needs (Rappaport, 1987). Profitability affects the firm's value because it is a measure of firm's performance as measured by the profit generated. Firms that succeed in gaining ever-increasing profit indicate that the firm has a good performance, therefore creating positive response from investors and encouraging a rise in the firm's stock price. High profitable firms means that the managers corporates wealth effectively and efficiently (Manu, et al., 2019).

Building upon the above issues, this study provides empirical evidence from Amman stock exchange (ASE) to address the effect of capital structure and profitability on the firm value of Jordanian manufacturing companies listed on the Amman stock exchange (ASE). The current study contributes to the literature in various ways. First: It adds more to the growing literature of capital structure, profitability and the firm's value. Second: Investigating the effects of capital structure, profitability on firm's value to justify the conflicting results in prior researches. Finally, the results of the study provide insights for investors, or any interested party in order to reach a better investment decisions. In particular, this study addresses the following questions:

1. Does capital structure affect firm's value?

2. Does profitability affect firm's value?

This study proceeds as follows: The following Section briefly reviews related literature and develops the study hypotheses. Section 3 describes the research methodology. Section 4 presents the empirical results, followed by Section 5 which contains a conclusion.

\section{Literature review and hypotheses development \\ 2.1 Capital structure and firm value}

Capital structure represents the proportions of the firm's financing from current and long-term debt and equity (Ross et.al. 2002). The literature on empirical capital structure has witnessed an on-going debate about whether higher leverage enhances or reduces firm's value. Leverage results from the use of fixed-cost assets or fund to magnify returns to the firm's owner, increase in leverage result in increased return and risk and the amount of leverage in the firm's capital structure can significantly affect its value by affecting return and risk (Gitman, 2003). The more debt a firm has, the more likely it is that the firm will become unable to fulfill its contractual obligation. On the positive side, debt provides a significant tax advantage because interest is tax deductible (Ross, et.al. 2002). "Managers should choose the capital structure that they believe will have the highest firm's value, because this capital structure will be the most beneficial to the firm's stockholders". The determination of a firm's capital structure constitutes a complex and difficult decision, one that involves several and antagonistic factors, (e.g., risk and profitability). Prior empirical studies of the relationship between capital structure and firm's value have yielded mixed results. (Manu, et al., 2019) found that capital structure has a positive and significant effect on firm's value. (Al-Najjar and Al-Najjar, 2017) provide evidence of a positive relationship between external financing and firm's value. (Kontesa, 2015) documented that there is a positive effect of capital structure on firm's value. (Soumadi and hayajneh, 2015) found that capital structure associated negatively and statistically with firm's value. (Agrawal and knoeber, 1996) found that there is a negative association between leverage and firm's value.

Considering the literature on the relationship between capital structure and firm's value, the following hypothesis can be formulated:

H1. Capital structure has a significant effect on firm's value of Jordanian manufacturing companies listed on the (ASE)

\subsection{Profitability and firm value}

Profitability represents the firm's ability to obtain profit in relation to sales, assets, and equity. It is the ratio of the effectiveness of management based on the returns generated from sales and investments (kontesa, 2015). High profitability affects firm's financial flexibility, so that the firm is able to pay dividends and obtained a positive rating in capital market (Manu, et al., 2019). Profitability allows investors to see how efficiently a firm spends its fund for its operational activities to earn higher profits. High profit reflects excellent corporate prospects, which attract investors to raise the demand upon firm's shares. A higher demand upon firm's share increases the firm's value (Rahayu, et al., 2019). (Manu, et al., 2019) stated that profitability has a positive effect on firm's value. (AlNajjar and Al-Najjar, 2017) reported that profitability is positively related to firm's value. (Kontesa, 2015) documented that there is a positive effect of profitability on firm's value. (Chen, et al., 2010) documented that highly profitable firms are more likely to have higher values.

Considering the literature on the relationship between profitability and firm's value, the following hypothesis can be formulated:

H2. Profitability has a significant effect on firm's value of Jordanian manufacturing companies listed on the (ASE) 


\section{Methodology \\ 3.1 Sample}

The study sample includes all Jordanian manufacturing companies listed on the Amman stock exchange (ASE). The analysis in this study is based on panel data over the period 2014-2018. We exclude financial sector companies because they have a different set of financial data and due to their distinctive working capital structure (Klein, 2002). However, the data from some companies were unavailable or insufficient in some years because of liquidation or merger; such companies were excluded from the sample set. The total number of Jordanian manufacturing companies listed on (ASE) in 2018 is 63 companies. The total number of companies analysed is (41), representing $(65.08 \%)$ of the original population and the total number of observations added up to (205). Data was obtained from (ASE) database and annual reports issued by Jordanian manufacturing public shareholding companies.

\subsection{Model specification and variables definition}

The study aims to examine the effect of capital structure and profitability on the firm's value of Jordanian manufacturing companies. Thus, capital structure and profitability are reflected as independent variables, while the firm's value is the dependent variable. The following general model is estimated:

Firm's Value $=f(C S$, Profit, $S I Z E+\varepsilon)(1)$

Where: Firm's Value: is the firm value, $\boldsymbol{C S}$ : capital structure, Profit: profitability, SIZE: is firm size, and $\varepsilon$ : error term. As a result to use two different measures for firm value (market value, and Tobin's $Q$ ), the general model in equation (1) above is implemented by dividing the general model into two detailed models as follows:

Model 1:

Model 2:

$$
\boldsymbol{M} \boldsymbol{V}_{i t}=\boldsymbol{\beta}_{0}+\boldsymbol{\beta}_{1} L E V_{i t}+\boldsymbol{\beta}_{2} \mathrm{DER}_{i t}+\boldsymbol{\beta}_{3} \mathrm{ROA}_{i t}+\boldsymbol{\beta}_{4} \mathrm{ROE}_{i t}+\boldsymbol{\beta}_{5} \mathrm{SIZE}_{i t}+\boldsymbol{\varepsilon}(\mathbf{1 . 1})
$$

Where:

$$
\text { Tobin's } \boldsymbol{Q}_{i t}=\boldsymbol{\beta}_{\mathbf{0}}+\boldsymbol{\beta}_{1} L E V_{i t}+\boldsymbol{\beta}_{\mathbf{2}} \mathrm{DER}_{i t}+\boldsymbol{\beta}_{\mathbf{3}} \mathrm{ROA}_{i t}+\boldsymbol{\beta}_{4} \mathrm{ROE}_{i t}+\boldsymbol{\beta}_{5} \mathrm{SIZE}_{i t}+\boldsymbol{\varepsilon} \text { (1.2) }
$$

$\boldsymbol{L E} \boldsymbol{V}_{i t}$ : leverage, total debt to total assets for firm $i$ in year $t$

$\boldsymbol{D E} \boldsymbol{R}_{i t}$ : Debt-to-equity ratio, total debt to total equity for firm $i$ in year $t$

$\boldsymbol{R} \boldsymbol{O} \boldsymbol{A}_{i t}:$ return on assets for firm $i$ in year $t$

$\boldsymbol{R} \boldsymbol{O} \boldsymbol{E}_{i t}:$ return on equity for firm $i$ in year $t$

$\boldsymbol{S I Z E}_{i t}$ : firm size, natural logarithm of total assets for firm $i$ in year $t$

$\boldsymbol{M} \boldsymbol{V}_{i t}$ : market value: natural logarithm of market value for firm $i$ in year $t$

Tobin's $\boldsymbol{Q}_{i t}$ : Tobin's $Q$ ratio for firm $i$ in year $t$

$\alpha:$ is the constant

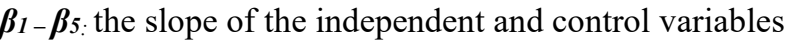
$\varepsilon$ : error term.

The dependent variable: firm's value which is measured using both market value and Tobin's $Q$.

Market value is defined as the market closing price-year end multiplied by the number of common shares outstanding (Cohen, et al., 2008). It is aimed to obtain more healthy results by decreasing the differences between values by logarithmic transformation; thus, Market value is measured by the natural logarithm of of mark value (Aras and Yildirim, 2018). The study also uses Tobin's $Q$ as alternate firm value measure for robustness tests. The advantage of Tobin's $Q$ is that it indicates the current value and potential future earnings of the firm. It measures value the investors put on a firm compared to the cost of setting up such a firm. If Tobin's $Q$ is greater than one, value has been added to firms over years, indicating a well-managed firm and if Tobin's $Q$ is less than one, value has disappeared (Alipour, 2013). Following prior studies (Manu, et al., 2019; Kao, et al, 2018; kontesa, 2015; Arouri, et al., 2014) Tobin's $Q$ is computed as the ratio of the sum of the market value of common shares and the book value of total debt divided by the book value of total assets.

The independent variable: this study used two independent variables; the capital structure variable composed by two indicators, namely, leverage and Debt-to-equity Ratio; the profitability variable composed by two indicators, namely, return on assets and return on equity.

Leverage ( $L E V)$ : determines the firm's long-term debt-paying ability. (Jensen and Meckling, 1976) identified leverage as a strong mechanism for solving the agency problem due to its ability to prevent managers from investing in value-destroying investments. Firms finance their activities through borrowing commit themselves to fixed charges that include principal payments and interest. Failure to repay debt may subject the company to risk of bankruptcy. Creditors would actively monitor the firm's capital structure to protect their own interest. Therefore leverage influences firm's performance (Arouri, et al., 2014). Leverage indicates the percentage of assets financed by creditors. The lower this ratio the better the firm's position (Gibson, 1995). Leverage was measured as the ratio of total debt to total assets (Kao, et al, 2018; Mouna, et al., 2017; kontesa, 2015).

Debt-to-equity ratio (DER): determines the firm's long-term debt-paying ability. The lower this ratio, the better the firm's debt position (Gibson, 1995). Debt-to-equity ratio is calculated as the ratio of total debt to total 
equity (Manu, et al., 2019; Kontesa, 2015).

Return on assets (ROA): measures the overall effectiveness of management in generating profits with its available assets (Gitman, 2003). Many studies on capital structure and performance use this measure (Manu, et al., 2019; Kao, et al, 2018; Mouna, et al., 2017; Alipour, 2013). ROA is computed as the ratio of net income after tax to total assets.

Return on equity (ROE): measures the return earned on the common Stockholder's investments in the firm. The higher this return, the better off is the owners (Gitman, 2003). Prior studies, such as (Manu, et al., 2019; Mouna, et al., 2017; kontesa, 2015) use a similar measurer. ROE is calculated as the ratio of net Income after tax to total equity.

Prior research suggests that firm's size may influence firm's value. Large companies have an advantage in raising external fund in capital markets and depend less on internal fund, which can have valuable effects on firm's performance and firm's value (Kao, et al, 2018). Larger companies may be more efficient, as they exploit economics of scale and have the ability to diversify risks, employ more skilled managers and targeting a large number of customers (Zouari and Taktak, 2014). Firm's size is measured by the natural logarithm of end of total assets (Mouna, et al., 2017).

Table (1) shows a summary of study variables and measurement.

Table (1) Study variables and their measurements

\begin{tabular}{|c|c|c|}
\hline Variable & Acronym & Measurement \\
\hline \multicolumn{3}{|c|}{ Dependent Variables } \\
\hline Market Value & MV & the natural logarithm of mark value \\
\hline Tobin's $Q$ & Tobin's $Q$ & $\begin{array}{l}\text { The ratio of the sum of the market value of common shares and } \\
\text { the book value of total debt divided by the book value of total } \\
\text { assets }\end{array}$ \\
\hline \multicolumn{3}{|c|}{ Independent Variables } \\
\hline Leverage & LEV & The ratio of total debt to total assets \\
\hline Debt to Equity & DER & The ratio of total debt to total equity \\
\hline Return on Assets & ROA & The ratio of net income after tax to total assets \\
\hline Return on Equity & ROE & the ratio of net Income after tax to total equity \\
\hline \multicolumn{3}{|l|}{ Control Variables } \\
\hline Firm size & SIZE & The natural logarithm of total assets \\
\hline
\end{tabular}

4. Empirical results

4.1 Descriptive statistics

Table (2) presents the descriptive statistics of the study variables (dependent and independent). It summarizes the mean value, standard deviation, minimum, and maximum of all variables used in the study as well as the number of firm-year observations over the sample period.

Table (2) descriptive statistics of both the dependent and the independent variables

\begin{tabular}{|c|c|c|c|c|c|}
\hline Variable & Observation & Mean & Standard deviation & minimum & Maximum \\
\hline 1. LEV & & 38.933 & 26.370 & 0.400 & 154.241 \\
\hline 2. DER & & 0.804 & 1.668 & 0.000 & 13.840 \\
\hline 3. ROA & & -1.796 & 17.590 & -195.296 & 36.071 \\
\hline 4. $\mathrm{ROE}$ & 205 & 2.451 & 10.702 & -52.800 & 32.050 \\
\hline 5. SIZE & & 16.806 & 1.569 & 12.680 & 20.920 \\
\hline 6. MV & & 14.230 & 2.201 & 9.100 & 18.300 \\
\hline 7. Tobin's $Q$ & & 0.894 & 0.421 & 0.170 & 1.960 \\
\hline
\end{tabular}

\subsection{Correlations analysis}

Table (3) presents the results of Pearson's correlations coefficients amongst all the study variables. The Pearson's correlations coefficients between each pair of explanatory variables should not exceed 0.80 (Gujarati, 2004). As shown in table (3) the correlation coefficients between all explanatory variables are not high and they are within the acceptable range. Suggesting no multicollinearity problem. 


\begin{tabular}{llllcccc}
\multicolumn{1}{c}{ Variable } & LEV & DER & ROA & ROE & SIZE & MV & Tobin's $Q$ \\
\hline 1. LEV & 1 & & & & & & \\
2. DER & -0.116 & 1 & & & & & \\
3. ROA & $-0.251^{* *}$ & 0.057 & 1 & & & & \\
4. ROE & -0.010 & $0.221^{* *}$ & 0.004 & 1 & & & \\
5. SIZE & -0.050 & 0.125 & $0.367^{* *}$ & 0.006 & 1 & & \\
6. MV & -0.007 & $0.202^{* *}$ & -0.114 & -0.069 & 0.122 & 1 & \\
7. Tobin's $Q$ & 0.013 & -0.031 & 0.013 & -0.001 & $-0.145^{*}$ & $-0.153^{*}$ & 1 \\
\hline
\end{tabular}

** Correlation is significant at the 0.01 level (2-tailed).

* Correlation is significant at the 0.05 level (2-tailed).

\subsection{The multicollinearity between independent variables}

Table (4) presents the results of Variance Inflation Factor (VIF) and Tolerance values (calculated as 1/VIF). As a rule of thumb, when VIF values exceeds 10 , and tolerance values are lower than 0.10 , it indicates to a potential multicollinearity problems (Hair et al., 2010). As shown in table (4), all VIF values for all variables are less than 10 , with the tolerance values that are more than 0.10 . These results support the Pearson's correlations coefficients and provide proof there is no serious of potential multicollinearity problems.

Table (4) The Results of Tolerance, VIF values

\begin{tabular}{lcc}
\hline \multicolumn{1}{c}{ Independent Variables } & Tolerance & VIF \\
\hline 1. LEV & 0.923 & 1.083 \\
2. DER & 0.924 & 1.082 \\
3. ROA & 0.811 & 1.233 \\
4. ROE & 0.951 & 1.052 \\
5. SIZE & 0.851 & 1.175 \\
\hline
\end{tabular}

\subsection{Regression analysis}

After making sure that all required conditions are satisfactory met, the study hypotheses were tested using multiple regression analysis in order to examine the effect of capital structure and profitability on the firm's value. Table (5) (model 1) shows the result of multiple regression equation that links capital structure and profitability with firm's value measured by market value. Table (6) (model 2) shows the result of multiple regression equation that links capital structure and profitability with firm's value measured by Tobin's $Q$. It can be noted from the indication of Adjusted $R^{2}$ and Sig. $F$ that the model 1 (dependent variable: market value) is more explanatory and powerful than the second model (dependent variable: Tobin's $Q$ ).

According to the model 1 (dependent variable: market value), the results reveal that the Adjusted $R^{2}$ is equal to (0.094). This indicates that the combination of the independent variables explain $9.4 \%$ of variation of the market value. Further, the result shows that the $F$-value equal (4.113) and it is significant at the significance level ( 0.05$)$ $\alpha \leq$. This indicates that there is a significant effect between capital structure and profitability on market value.

As seen from table (5), the results found that DER has significant effect on market value and the direction of the relationship is positive, ROA has significant effect on market value and the direction of the relationship is negative. While the other variables; LEV and ROE have no significant effect on market value. Regarding the firm size (the natural logarithm of end of year total assets of the company) the results found that it has has significant effect on market value and the direction of the relationship is positive; larger companies tend to perform better than small companies.

The results of this research support the previous research finding of (Soumadi and hayajneh, 2015) who found that capital structure associated negatively and statistically with firm's value, (Agrawal and knoeber, 1996) who found that there is a negative association between leverage and firm's value, (Al-Najjar and Al-Najjar, 2017) who reported that the firm size is positively related to firm' value. In addition, this result contrasts what was mentioned in the study of (Manu, et al., 2019) who found that capital structure has a positive and significant effect on firm's value, (Al-Najjar and Al-Najjar, 2017) who provide evidence of a positive relationship between external financing and firm's value, (Kontesa, 2015) who documented that there is a positive effect of capital structure on firm's value, (Agrawal and knoeber, 1996) who found that there is a negative association between firm size and firm's value. 
Independent Variable: MV

\begin{tabular}{lcccc}
\hline Dependent Variables & B & Beta & t & Sig. \\
\hline 1. LEV & -0.002 & -0.023 & -0.322 & 0.748 \\
2. DER & 0.284 & 0.215 & 3.069 & 0.002 \\
3. ROA & -0.024 & -0.192 & -2.557 & 0.011 \\
4. ROE & -0.024 & -0.117 & -1.691 & 0.092 \\
5. SIZE & 0.231 & 0.165 & 2.255 & 0.025 \\
Constant & 10.203 & & 5.891 & 0.000 \\
$R$ & 0.306 & & & \\
$R^{2}$ & 0.094 & & & \\
Adjusted $R^{2}$ & 0.071 & & & \\
$F$ & 4.113 & & & \\
Sig. & 0.001 & & & \\
\hline Statisticaly & & & & \\
\end{tabular}

Table (5) Results of multiple regressions Model 1

* Statistically significant at the significance level $(\alpha \leq 0.05)$

According to the model 2 (dependent variable: Tobin's $Q$ ), It can be seen form Table (6) that the $F$-value is 1.092 and it is not significant at the significance level $(\alpha \leq 0.05)$, which indicate that there is no significant effect between all of the independent variables (capital structure and profitability variables) and Tobin's $Q$. Regarding the firm size (the natural logarithm of end of year total assets of the company) the results found that it has significant effect on Tobin's $Q$ and the direction of the relationship is negative. The results of this research support the previous research finding of (Khamis, et al., 2015) who found that firm size has a negative and significant effect on firm's value measured by Tobin's $Q$, (Soumadi and hayajneh, 2015) who found that capital structure associated negatively and statistically with firm's value (Tobin's $Q$ ). In addition, this result contrasts what was mentioned in the study of (Rahayu, et al., 2019) who found that profitability has a positive and significant influence on firm's value, (Manu, et al., 2019) who stated that profitability has a positive and significant effect on firm's value, (Al-Najjar and Al-Najjar, 2017) who reported that profitability is positively related to firm's value, (Kontesa, 2015) who documented that there is a positive and significant effect of profitability and capital structure (DER) on firm's value measured by Tobin's $Q$, (Chen, et al., 2010) who documented that highly profitable firms are more likely to have higher values. Also, he reported that there is a positive association between size and Tobin's $Q$

Table (6) Results of multiple regressions Model 2

\begin{tabular}{lcccc}
\hline Independent Variable: Tobin's $Q$ & & & & \\
\hline Dependent Variables & B & Beta & t & Sig. \\
\hline 1. LEV & 0.000 & 0.023 & 0.322 & 0.748 \\
2. DER & -0.003 & -0.012 & -0.162 & 0.871 \\
3. ROA & 0.002 & 0.083 & 1.068 & 0.287 \\
4. ROE & 0.000 & 0.003 & 0.036 & 0.972 \\
5. SIZE & -0.046 & -0.172 & -2.276 & 0.024 \\
Constant & 1.663 & & 4.844 & 0.000 \\
$R$ & 0.163 & & & \\
$R^{2}$ & 0.027 & & & \\
Adjusted $R^{2}$ & 0.002 & & & \\
$F$ & 1.092 & & & \\
Sig. & 0.366 & & & \\
\hline
\end{tabular}

* Statistically significant at the significance level $(\alpha \leq 0.05)$

\section{Conclusion}

This study aimed to provide empirical evidence from Amman stock exchange (ASE) to address the impact of capital structure and profitability on the firm value of Jordanian manufacturing companies listed on (ASE). The total number of Jordanian manufacturing companies listed on (ASE) in 2018 is 63 companies. The total number of companies analysed is (41), representing (65.08\%) of the original population and the total number of observations added up to (205). Data was obtained from (ASE) database and annual reports issued by Jordanian manufacturing public shareholding companies. The study built two different regression models to study the effect of capital structure and profitability on the firm's value. The first model used market value and the second model used Tobin's $Q$ as an indicator of firm's value. Two firm's value indicators are used as dependent variables to capture features of each measure and possibility of changing results. The study reveals different results by using different firm's value measures. When using the first model (market value) the results found that DER has significant effect on market value and the direction of the relationship is positive, while ROA has significant effect on market value and the direction of the relationship is negative. However, when the second model (Tobin's $Q$ ) 
used the results found that there is no significant effect between all of the independent variables (capital structure and profitability variables) and Tobin's $Q$. The results of the study were conflicting regarding the effect of firm size on firm's value. The firm size has a positive and significant effect on market value; while it has a negative and significant effect on Tobin's $Q$.

This study has several limitations. First, the research was carried out in Jordan. Therefore the findings are more likely to have limited application to other countries. Second, this study is done in industrial sector due to time and other resource constraints, so it is recommended for future researchers to do study in other sectors, and consider other factors which researcher did not deal with them in this study, also the study found that the market value model is more explanatory and powerful to firm's value rather than the Tobin's $Q$ model but this needs further investigation by future research.

\section{References}

Agrawal, A., and knoeber, C.R., (1996), "Firm performance and mechanism to control agency problems between managers and shareholders", Journal of Financial and Quantitative Analysis, Vol.31, No.3, pp.377-397.

Alipour, Mohammad, (2013), "An investigation of the association between ownership structure and corporate performance: Empirical evidence from Tehran Stock Exchange (TSE)", Management Research Review, Vol.36, No.11, pp.1137-1166.

Al-Najjar, B., and Al-Najjar, D., (2017), "The impact of external financing on firm value and a corporate governance index: SME evidence" Journal of Small Business and Enterprise Development, Vol.24, No.2, pp.411-423.

Al-Nsour, Osama and Jresat, Sami, (2018), "Capital Structure and Performance: Applied Study on Jordanian Industrial Public Shareholding Companies Listed in Amman Stock Exchange (ASE)", Journal of Economic and Financial Research, Vol.5, No.2, pp. 601-621.

Aras, G., and Yildirim, F., (2018), "The impact of corporate finance decision on market value in emerging markets", International Journal of Productivity and Performance Management, Vol.67, No.9, pp.19591976.

Arouri, Houda, Hossain, Mohammad, and Muttakin, Mohammad Badrul, (2014), "Effects of board and ownership structure on corporate performance: Evidence from GCC countries", Journal of Accounting in Emerging Economics, Vol.4, No.1, pp.117-130.

Chen, W.P., Chung, H., Hsu, T.L., and Wu, S., (2010), "External financing needs, corporate governance, and firm value", Corporate Governance: An International Review, Vol.18, No.3, pp.234-249.

Cohen, D.A, A., Dey, and T.Z., Lys, (2008), Real and Accrual-based Earning Management in the Pre and PostSarbanes Oxley Periods, The Accounting Review, Vol.83, No.2. P. 757-787.

Gibson, Charles, H., (1995), “Financial Statement Analysis Using Financial accounting Information”, 6th edition, South- Western College Publishing.

Gitman, Lawrence, J., (2003), "Principle of Managerial Finance", 10th edition, The Addison- Wesley.

Gujarati, D., (2004), Basic Econometrics. $4^{\text {th }}$ ed., McGraw-Hill., New York, USA.

Hair, J., and Black, W., and Babin, B., and Anderson, R., (2010), "SEM: an introduction", "Multivariate data Analysis: A global Perspectives”, 7th edition, Pearson Education, Inc., Saddle River, New Jersy.

Jensen, M.C., and Meckling, W.H., (1976).” Theory of the firm: managerial behavior, agency costs and capital structure", Journal of Financial Economics, Vol.3, pp.305-360.

Jensen, M.C., and Meckling, W.H., (1976)." Theory of the firm: managerial behavior, agency costs and capital structure", Journal of Financial Economics, Vol.3, pp.305-360.

Kao, Mao-Feng, Hodgkinson, Lynn, and Jaafar, Aziz, (2018), "Ownership structure, board of directors and firm performance: evidence from Taiwan”, Corporate Governance, DOI 10.1108/CG-04-2018-0144.

Khamis, Reem, Elali, Wajeeh, Hamdan, Allam, (2015), "The effect of dividends and institutional ownership on performance of companies listed in Bahrain Stock Exchange, Jordan Journal of Business Administration, Vol.11, No.4, pp. 921-941.

Klein, A., (2002), "Audit committee, board of director characteristics, and earning management", Journal of Accounting and Economics, Vol.33, No.3, pp.375-400.

Kontesa, Maria, (2015),"Capital structure, profitability, and Firm Value, What's New?" Research Journal of Finance and Accounting, Vol. 6, No. 20, 185-192.

Manu, R., Alhabsji, T., Rahayu, S., and Nuzula, N., (2019), "The effect of corporate governance on profitability, capital structure and corporate value", Research Journal of Finance and Accounting, Vol.10, No.8, pp.202214.

Modigliani, F., and Miller, M.H., (1958), "The cost of capital, corporation finance and the theory of investment", American Economic Review, Vol.48, No.3, pp.261-297.

Mouna, A., Jianmu, Y., Havidz, S., and Ali, H., (2017), "The impact of capital structure on firms performance in Morocco", International Journal of Application or Innovation in Engineering \& Management, Vol.6, 
No.10, pp.11-16.

Musah, A., (2017), "The impact of capital structure on profitability of commercial banks in Ghana", Asian Journal of Economic Modelling, Vol.6, No.1, pp. 21-36.

Rahayu, S.M., Saif, S., and Saif, M., (2019), "the reciprocal relationship between profitability and capital structure and its impacts on corporate values of manufacturing companies in Indonesia", International Journal of Productivity and Performance Management, DOI 10.1108/IJPPM-05-2018-0196

Rappaport, A., (1987), "Linking competitive strategy and shareholder value analysis", The Journal of Business Strategy, Vol.3, pp.58-67.

Ross, Stephen A., and Westerfield, Randolph W., and Jaffe, Jeffrey, (2002), “Corporate Finance”, 6th edition, McGraw-Hill.

Siam, Walid Z., and Khrawish, Husni A., and El-Hammoury, Basem M., (2005), "The capital structure of banking sector in Jordan”, Dirasat, Administrative Sciences, Vol.32, No.1, pp. 196-207.

Soumadi, M., and hayajneh, O., (2015), "Capital structure and corporate performance: Empirical study of the public Jordanian shareholdings firms listed in Amman stock exchange", Research Journal of Finance and Accounting, Vol. 6, No. 4, 1-9.

Zouari, Sarra Ben Slama, and Taktak, Neila Boulila, (2014), "Ownership structure and financial performance in Islamic banks: Does bank ownership matter?”, International Journal of Islamic and Middle Eastern Finance and Management, Vol.7, No.2, pp.146-160. 